\title{
Transnational History of Imperial Council of Agricultural Research, 1929-1947
}

\author{
Vinod Kumar Singh* \\ (Received 14 April 2018; revised 28 May 2018)
}

\begin{abstract}
The paper explores the role of Imperial Council of Agricultural Research (ICAR) in coordinating and controlling different agricultural research institutions in colonial India from 1929 to 1947. The paper will closely examine the debate on uniform agricultural improvement methods as per the recommendation of the Royal Commission of Agriculture (1928) that eventually culminated by 1965 in the integration of provincial research stations, commodity committees, agricultural departments and central institutions under a single institution called the ICAR (1929). Decentralized power between the centre and provinces made coordination and control of several agricultural organizations a tedious function for the ICAR to perform. The evolution of ICAR over the period of time is indicative of negotiations it made to avail central government patronage so as to confer economic outputs from its research programmes besides augmenting its relevance for enquiry. In doing so, the paper draws attention to history of agricultural institutions and their several transnational interactions to understand the power and knowledge relations between the Imperial state and its institutions. The paper points out that the utilitarian agenda of colonial research and education steered the concerns of the Indian agricultural research system during the Green Revolution years. The proposed paper will map this transformation while focusing on the transnational history of the ICAR.
\end{abstract}

Key words: Agricultural research, Circulation of knowledge, Colonialism, Disease resistant varieties, Green revolution, Hybrid maize, Industry, Potato, Sugarcane.

\section{INTRODUCTION}

In 1905, Imperial Agricultural Research Institute (IARI), Pusa (North Bihar) took shape and the Board of Agriculture in India started coordinating the agricultural research. Considering the traditional knowledge of farming communities, the British scientists like Albert Howard proposed the 'modern' agricultural experts to 'go back to farmers' (Sen, 2010, p. 227). Howard was not quite happy with the direction of agricultural research at Pusa in mid-1920s. Being amongst the first researchers (many came to India in 1905) at Pusa, they thought that the agricultural research at Pusa was getting heavily compart- mentalized and hence walked out and started working at their own research station-Institute of Plant Industry at Indore. The quest of British Scientists at institutes and provincial research stations to make independent enquiry along with the concerns of provincial governments to outdo the Government of India supported cross-cultural knowledge systems (Kumar, 2000, p. 243).

The challenge of global economic crisis of 1930s had impacted the role and organization of agricultural research under the ICAR. Latter evolved its research priority keeping the selective economic output amidst fall in the real wage as a consequence of depression affecting income and

\footnotetext{
* PhD research scholar, Studies in Science, Technology and Innovation Policy, Central University of Gujarat, Sector 29, Gandhinagar, India-382029; E-mail address: vs6460@gmail.com
} 
employment of agricultural labour (Mishra, 2016, p. 263). In these turbulent times, Bernard Augustus Keen was seconded from Rothamsted Experimental Station from 1929-31 to be the Director of the IARI (Pereira, 1982, p. 210). He was sent proverbially 'to put the house in order' and his scathing criticism regarding bureaucratization of agricultural research leads up to strong advocacy for 'academic autonomy' to fundamental scientific enquiry. Experimental trials on the sugarcane-sorghum cross at the Coimbatore sugarcane research station successfully travelled from Hawaii, Java and Florida to Tamil Nadu, Uttar Pradesh and Bihar (Randhawa, 1983, p. 336). Agricultural research generating export and better commodities for industrial purposes introduced the concept of marketing surveys for specified grain characteristics at research stations under the ICAR.

\section{Agricultural Institutions and Nature of Agricultural Researches}

The colonial knowledge generation for scientific agriculture undertook social, economic and political relations among cultivators, landlords, industries and the British government. Initially, agricultural research was being controlled by the Department of Agriculture with establishment of semi-autonomous commodity committees on cotton, lac, jute, sugarcane, coconut, tobacco, oilseeds, cashew nut, areca nut and spices. There were several independent research institutions such as the Cotton Technology Research Laboratory at Bombay, Indian Lac Research Institute at Ranchi, Jute Agricultural Research Laboratory at Dacca, Coconut Research Stations at Kayankulam and Kasaragod, Indian Institute of Sugarcane Research at Lucknow, and the Central Tobacco Research Institute at Rajahmundry. Autonomy of regional and local research in provinces and universities introduced multilayered 'agency' and 'structure' contestations against central coordination of agricultural research among scientists, institutions and colonial state. However, ecological protection from use of research results, nutrient's preservation in crops, cost-effective solution to farmer's problem and integration of scientific research with village economy remained intact in the hierarchy of knowledge generation (Raina, 2003, p. 107). The origin of research problem had allegiance in farmer's problems to an extent that Nationalist political struggle supported them against British Raj. In this direction, universities in provinces examined more closely research work in the sciences basic to agriculture, and bring together the results of the work carried out so far on the different crops and other subjects (Anonymous, 1938 , p. 467). The paradigm of scientists under the influence of Internationalist moment also created the value system in 'science for all', where studies in protein and vitamin content in rural diet was undertaken.

The quest for 'quality' improvements in the provincial agricultural departments and princely states by 1932 came out of surplus production in crops around the Great Economic Depression and the Second World War. Export trade decline in agricultural crops prevented 'productionist' discourse, where agriculturists and industrialists under the ICAR held joint conferences to decide on the most suitable problems for investigation (Anonymous, 1932, p. 29). The Mysore state realized effectiveness of the biological insect control method in 1935 (Minister of Agriculture Canada, March 1933, p. 499). These unconnected research trials made no an easy task for the central research institutes to apply artificial chemical insecticides experimentation throughout larger cultivation fields. A decade later the Central Rice Research Institute (CRRI), Cuttack (1946) was established to introduce cross-breeding for high yielding rice varieties with the help of Dr. K. Ramiah and FAO (Food and Agriculture Organization). Partnership in the knowledge creation and dissemination worked in a multi-site process to be evolving at the CRRI and applied to 
transnational breeding programmes at the IRRI (International Rice Research Institute), Philippines, and the USA (Randhawa, 1979, p. 143). Disciplinary approach in institutional research shifted the concentration of local knowledge to be assimilated and reproduced into new forms of cross-cultural knowledge systems based on economic return. In that case, cotton was transformed in quality to develop long lint high yielding varieties for global market competition against local varieties (Pray, June 1984, p. 431).

The ICAR tried to manipulate investigation of many problems in agriculture at a time in 1935 to gain single-hand expertise in dealing with complexities of crops and animals. Agricultural research introducing synthetic fertilizers with irrigation departments planned for larger cultivation areas, in turn displaced cheaper millets and jowar crops as 'inferior strains' to improve production in rice. The idea of agriculture as industry got developed with 'Pusa Wheats' for abroad besides at the Coimbatore sugarcane station of the IARI. An interesting line of knowledge production in 1939 on problems of soil fertility, cultivation and plant nutrition were done in order to explore cheap methods of nitrogen nutrition to soils and crops through suitable soil management and crop rotation (Anonymous, 1939, p. 247). Beyond question, it was the practice of transnational science where indigenous farming practices were explored in making adjustments for preliminary structural transformation to create knowledge and institutions guided by political and economic priorities. The emergence of specialized laboratories and technological institutes marks the transnational market experimentation in desired qualities of agricultural produce. To illustrate, the Punjab Agricultural College and Research Institute established in 1906 at Lyallpur carried out extensive amalgamation of life-sciences discipline into indigenous farming techniques. Following this, experimental farms were involved in testing rotational cropping; developing seeds comfortable with soils and manures, and the ICAR sponsored schemes in 1939-40 on Wheat Technology and Wheat Milling and Baking Tests (Mohan, 2018, p. 212).

The ICAR and its institutions in the early 1940s initiated all-India programmes for better coordination of research to be carried out in the provinces and states. To realize coordination objectives, the ICAR appointed a separate scientific committee for each science or group of sciences and each of these committees by itself or in cooperation with others provides the machinery by which the research programmes are to be initiated, reviewed and coordinated (ICAR 194142 , p. i). The combined agricultural and animal husbandry research as village projects came into light by 1945 , where emphasis was given to introduce modern agricultural implements with marketing strategies. These attempts at mixed farming carried seeds of American technoscientific model along with preservation methods for cattle manure in rehabilitating subsidiary industries (ICAR 1945-46, p. 30). Moreover, the selective agricultural research priorities by the British Raj never allowed concrete and regular funding for long-term academic science in the universities. Latter as the primary centre of agricultural research was marginalized to a lesser extent by the colonial state due to the ICAR failed attempt to coordinate and control these institutions in provinces (Raina and Jain, 859-878). In midst of these contestations between 'Big Science' and 'Academic Science' in agricultural research, the Bengal Famine of 1943 exposed the utilitarian agendas of the Imperial government. The 'Grow More Food' campaign launched in the same year and after the Second World War shaped the rhetoric of 'development' and 'modernization'. Again, the colonial state tried to garner public support for short-term projects in agriculture posing values of 'self-reliance' in surplus food production travelled by 1965 as the Green Revolution to establish technoscience dominance 
(Varughese, 2015, p. 143). To recapitulate, the decentralized agricultural research in British India developed networks of heterogeneous scientific institutions and universities owing to unstable political-economy of the colonial state.

\section{Role of The ICAR in Transnational Agricultural ReSEarch}

The prime reason for introducing investigations on cereal rust and virus disease of plants was due to usage of transnational materials at various research stations. For instance, there were no locust invasions in agricultural fields around 1932-33, although the ICAR continued its research in anticipation of its spread sooner or later (ICAR 1932-33, p. 20). The development of disease resistant varieties with predetermined commercial properties made the intention of ICAR to be free from any economic loss. In line with these researches, the deputation of B N Uppal to Europe and America was done in 1932-33 for the study of research on virus diseases of plants through most effective methods (ICAR 1934-35, p. 18). The transnational exchange of scientists and varieties through the institutional framework of the ICAR enabled cereals and plantation crops to contribute in knowledge formation worldwide. The research schemes in rice became another beneficiary of transnational connections that involved breeding, genetic and growth studies extensively in the provinces such as Madras, Bengal and Burma as per the local context. Further enquiry at the Burma research stations by the ICAR in 1934-35 included the study of exotic varieties of rice received from America, Japan, Formosa, China, Egypt and Java, investigations into the effects of different methods of drying and storing, on quality and milling and investigations into the effects of soil and climatic conditions on the quality of rice (ICAR 1935-36, p. 11). In the case of fruit research, it was Hofmeyr of South Africa who helped the ICAR in its Papaya seeds selection programme under genetic studies with consultation of institutions in England, South Africa, Australia, and United States (ICAR, 193940, p. 14).

Some of the fundamental researches were allowed at the IARI, but that also got reduced to imperatives of commercial/surplus production once ICAR tried to pull a part of its research programmes through funding in post-independent India. That is why the early improvements in hybridization programmes before 1930s in wheat at the IARI by Sir Albert and Gabrielle Howard and by expert R D Singh in Punjab somewhat took care of general cultivation problems of farmers. Benjamin Peary Pal as the Second Economic Botanist at IARI in 1930s focused on developing rust-resistant wheat varieties that could respond well with fertilizers to boost production. He became the Director of IARI and the DirectorGeneral of ICAR to organize all-India coordinated research projects in wheat over the three decades of developing interdisciplinary and interinstitutional cooperation in basic and applied research (Swaminathan, 1996, p. 267). The introduction of 'C 518' wheat variety which had properties of stiff straw and resistance to lodging conditions on Indian farming fields were even supplied to Canada and Mexico (Randhawa, 1983, p. 345). In post-colonial India, again meddling with these varieties and others, the United States would try to bring back to India 'hybrid' wheat during 'Green Revolution' by 1965. Here, the strength of research lies in creation of varieties that experienced longer time period of experimentation, supplemented with cheap indigenous manures. And if there were any chances of pests coming into the field, it was done away with the method called biological pest control. Apparently, farmers were having somewhat share in influencing research priorities of the scientists. The difference in enquiry of wheat before ICAR was that it looked largely into varieties for regional indigenous 'capātī-making' qualities for rural households. Whereas in the second phase of wheat 
development, the ICAR gave patronage to research on the disease resistance while compromising the nutritional aspects in front of the baking qualities for industrial flour production in the Britain. Thus, British India, with the assistance of ICAR tried to build a 'testing laboratory' for transnational scientific knowledge creation that could be used in Britain and other parts of the empire (Baber, 1996, p. 186).

In the 1943, ICAR also worked on a method of converting town refuse into cheap manure with the help of Indian Institute of Science, Bangalore (Food Production Branch, 7-1/43-P, p. 2). As a result of supporting local, cheap and sustainable methods of experimentation, the ICAR catered to the pressures of institutions that were not ready to change research problems under bureaucratic framework. The development of foreign varieties or mass selection from local types by employing the United States method of 'hybrid seed' in the shape of maize breeding got conceived at the IARI and Punjab as well. Above all, considering the practical aspect of food needs by the British India due to the Bengal famine (1943) came up with an initial modification into the knowledge system of agriculture towards abundance framework of the United States. Evidently, food needs for indigenous population got intertwined strategically into same colonial and transnational influence of knowledge creation for a sizeable world market under the ICAR. The Advisory Board approved a programme 'Coordinated Research on Pulses and Millets' in 1941, which represents the staple food of people throughout colonial India. However, only modified work kept the fact straight that it should not incur a very large additional expenditure and that the staff employed for pulses should, as far as practicable, be used for the millets work (ICAR, 1941-42, p. 11). The organization of food crops on the basis of United States transnational supply of expertise and funds for establishing maize research in the ICAR schemes tells the story of marginalization for pulses, millets, jowār, and $b \overline{a j r a}$ as rural life and culture dependent on it (Agriculture Section, 20-13/45-A, p. 9). For example, the food industry supplying burgers, corns and other transnational fast foods all over the world. What about if rural crops in India developed through research served as better alternatives of food from economic, social and political viewpoint that world would have been consuming?

Experts developed hybrid maize seeds somehow foreordained a chain reaction that would integrate other technoscientific research in laboratories fit for its production. The use of inputs like chemical fertilizers and pesticides then became dire necessity by 1965 to push surplus productions of these hybrid crops (Saha, 2013, p. 202). Connected to this inaugural popularization of 'hybrid vigour' by the United States made certain to establish similar sets of transnational agricultural knowledge transfer catering to its corn industry. The ICAR in its transnational character of research schemes tried to develop market and knowledge for an integrated central agricultural research system with other countries. Working on the development of fruit production in the provincial research stations, the ICAR in 1943 started a series of experiments on requirements of artificial manures. On the other hand, some of the provinces and states also had their own fruit research stations independent of the control and coordination of the ICAR (Food Production Branch, 7-2/43, p. 2). Latter had been involved to supply ammonium sulphate, superphosphate, niciphos and other manures to the Central Provinces for manurial experiments, as demand marked rather high comparatively to the independent provincial fruit research stations.

Research priorities for the specific crops were not done easily with the interest of agricultural research and its knowledge formation in itself. It was the need of hour to fight famines after the Second World War and development of 
agri-business model for the developed countries. Hence, circulation of knowledge and expertise determined by turbulent political-economy of the world affected research priorities in every nation. As a result of this, the ICAR scheme for potato breeding in Northern India by 1944 encapsulated development of genetic diversity within commercial varieties in less time. These hybrid crop seeds had potential to replace traditional potato varieties, where tubers were small and took uneven growth period. The cultivation mission of potato in South American region embarked on supplying readymade food to the workers in factories. Potato was liked by several agro-industrial business models for providing food to a large number of populations because potatoes takes less time to cook, being 'Carbohydrate' rich food option for the working people in industrialized countries. Pushing the potato production to a higher level in the US made China and India held their discussion on the lines of potato research in respective countries. Flow of expertise across national boundaries took place with T P Dykstar, the American Potato expert, who had been also in charge of the 'Chinese Potato Improvement Programme', while returning back to the US paid a brief visit to India (Agriculture Section, 21-112/ 44-A, p. 83). Linked with these achievements of surplus food production, the United States discovered other business alternatives by the organization and development of a seed potato industry at the demise of British rule in India. Here, the ICAR requested the IARI to prepare a comprehensive account of the commercial varieties of potatoes in India in the form of bulletin to be submitted for publication (Ibid). The Russians discovered certain species and hybrids in the South and Central America, that when experimented with the $S$. tuberosum developed resistance to the virus diseases and cold. Surprisingly, the two specific problems of the Russia and the United States varieties became matter of experimentation in India. Moreover, extensive work with the full collection of the
Solanum species and varieties collected by the Empire Potato Expedition was being done at Cambridge.

N L Dutt, Coimbatore Sugarcane Station, was conferred orders to undertake a survey of the sugarcane research work being financed by the ICAR in addition to his own line of research work [Planning Section, F-9(1)/45-PL, p. 19]. Another frustration for the ICAR was powerful position the Central Commodity Committees had with the Education, Health and Lands Department. The Central Commodity Committees related to Coffee and Tea were different than other cash crops because these commodities worked under the control of other departments. Such decentralized and multiple models of research hindered the development work in the need of crisis. Thus, the Imperial government lacked central agency to direct these institutions, even during the war, to boost up production to meet the deficiencies of food, livestock, fodder and manure [General Branch, 1(7)/45-PL, p. 19]. Nevertheless, these institutional arrangements partly under the ICAR and independent of the ICAR served the 'convenience' of scientific research along decentralized administrative system according to the stakeholders. The priorities of scientists through transnational research networks never allowed Imperial government to maintain bureaucratic hold for knowledge creation and that opened up many possibilities for the ICAR in the midst of uneven regulation of fund to be negotiating with regional research stations to also help them silently while being part of their research problems. This can be clearly understood from the case of import of certain packages in 1942 from the United States for sugarcane expert at Coimbatore research station. As a corollary, the researchers developed cane sugar seeds, which in 1943 supplied to Ibrahim Menchary of the Ministry of Agriculture, Egypt through the Imperial Agricultural Research Institute [Planning Section, F-9(1)/45-PL, p. 14]. 


\section{Conclusion}

In a nutshell, the ICAR supported research stations to carry out breeding programmes for high yield, desired commercial characteristics, and disease withstanding traits in crops through movement of scientists and varieties at the interface of transnational institutions. The general research programmes were to develop pure line selections that would replace traditional varieties of crops in relation to priorities of research in other countries. The growth, physiological behaviour and fundamental knowledge of crops were done with reference to adjustments made in adapting varieties of crops across the globe.

\section{ACKNOWLEDGEMENTS}

The author is grateful to the Indian National Science Academy, New Delhi for academic support to carry out the research work in history of science. It is essential to show the gratitude to Shiju Sam Varughese, Rajeswari S Raina, Dhruv Raina, Deepak Kumar and others as mentors in developing the ideas in the paper.

\section{BibLIOGRAPHY}

Agriculture Section. Department of Agriculture, ICAR Scheme for the Improvement of Maize Crop in IndiaAcceptance of a Grant of Rs. 46,900 for a Period of Five Years with effect from the 1st April 1946, (20-13/ 45-A), National Archives of India, New Delhi, 1945.

Agriculture Section. Ministry of Agriculture, ICAR Scheme for Potato Breeding in Northern India-Deputation of Dr. Pushkar Nath to the UK, [(21-112/44-A)], National Archives of India, New Delhi, 1944.

Anonymous. The Future of Agriculture in India, Current Science, 1.2 (August 1932): 28-30.

Anonymous . The Imperial Agriculture Research Institute, Current Science, 8.6 (June 1939): 245-248.

Anonymous. The Improvement of Indian Agriculture, Current Science, 6.9 (March 1938): 467-468.

Annual Report of the Imperial Council of Agricultural Research for the Year 1932-33, 1934-35, 1935-36, 1939-40, 1941-42, 1945-46, Government of India Press, New Delhi.
Annual Report of the Minister of Agriculture for the Dominion of Canada for the Year March 1933.

Baber, Zaheer. The Science of Empire: Scientific Knowledge, Civilization, and Colonial Rule in India, State University of New York Press, New York, 1996.

Food Production Branch. Education, Health \& Land Department, Planning and Coordinating future Agricultural Research-Recommendations of ICAR Advisory Board-Protection of Stored Grains and Standing Crops-Cheap Manure from Town RefusePress Note, [(7-1/43-P)], [(7-2/43)], National Archives of India, New Delhi, 1943.

General Branch. Department of Imperial Council of Agricultural Research, Reorganization of the Imperial Council of Agricultural Research with reference to the Recommendations made in the Memorandum on Agricological Development in India, [1(7)/45-PL], National Archives of India, New Delhi, 1945.

Kumar, Deepak. Reconstructing India: Disunity in the Science and Technology for Development Discourse, 1900-1947, Osiris, 15.1 (2000): 241-257.

Mishra, S M. 'Agrarian Distress: The Political Economy of British India in the 1930s', in Deepak Kumar and Bipasha Raha (eds.), Tilling the Land: Agricultural Knowledge and Practices in Colonial India, Primus Books, Delhi, 2016, pp. 260-281.

Mohan, Kamlesh. Punjab Agricultural College and Research Institute, Lyallpur (1906-1947): Generating Knowledge for Colonial Enrichment, Indian Journal of History of Science, 53.2 (2018): 205-223.

Pereira, Charles. Bernard Augustus Keen. 5 September 1890-5 August 1981, Biographical Memoirs of Fellows of the Royal Society, 28 (November 1982): 204-223.

Planning Section. Department of Imperial Council of Agricultural Research, [F-9(1)/45-PL)], National Archives of India, New Delhi, 1945.

Pray, Carl E. The Impact of Agricultural Research in British India, The Journal of Economic History, 44.2 (June 1984): 429-440.

Raina, Dhruv and Ashok Jain. Big Science and the University in India, in John Krige and Dominique Pestre (eds.), Science in the Twentieth Century, Harwood Academic Publishers, Amsterdam, 1997, pp. 859-878.

Raina, Rajeswari S. Institutions and Organisations: Enabling Reforms in Indian Agricultural Research and Policy, 
International Journal of Technology Management and Sustainable Development, 2.2 (2003): 97-116.

Randhawa, M S. A History of the Indian Council of Agricultural Research, 1929-1979, Indian Council of Agricultural Research, New Delhi, 1979.

Randhawa, M S. A History of Agriculture in India, 17571947, Vol. III, Indian Council of Agricultural Research, New Delhi, 1983.

Saha, Madhumita. The State, Scientists, and Staple Crops: Agricultural 'Modernisation' in Pre-Green Revolution India, Agricultural History, 87.2 (Spring 2013): 201223.
Sen, Srabani. Scientific Enquiry in Agriculture in Colonial India: A Historical Perspective, IJHS, 45.2 (2010): 199-239.

Swaminathan, M S. Benjamin Peary Pal. 26 May 1906-14 September 1989, Biographical Memoirs of Fellows of the Royal Society, 42 (November 1996): 266-274.

Varughese, Shiju Sam. 'The State-Technoscience Duo in India: A Brief History of a Politico-Epistemological Contract', in Axel Jansen, Andreas Franzmann and Peter Munte (eds.), Legitimizing Science: National and Global Publics (1800-210), Campus Verlag, Frankfurt and New York, 2015, pp. 137-156. 